\title{
Study on the Factors Affecting Senior Middle School Students' Selection of Majors of Hospitality and Catering
}

\author{
Yi-Hsueh Shen \\ Instructor/Department of Hospitality Management, Jen-teh Junior College of Medicine, Nursing and \\ Management, Miaoli, Taiwan
}

\begin{abstract}
In order to have holistic individual development, besides the intention of an individual, national education guidelines and enterprise demands must be considered in terms of national education. The selection of a school of a higher grade not only matters personal livelihood but also the survival and competition of a country, which must keep up with the times and be studied.

This study adopted Modified Delphi Method to summarize the opinions of experts, analyzed the primary and secondary influencing criteria, employed Analytic Hierarchy Process (AHP) to analyze samples to determine the relative weight of each criterion, and concluded the weight relationship of the factors influencing graduates of senior middle schools majoring in hospitality and catering. The results of this study show that there are five factors influencing students' selection of hospitality and catering which are interest, aptitude, parental education attitude, parents' expectations, and understanding of the work of hospitality and catering in order. The conclusion can serve as reference for educational and administrative organs, educational decision makers, post-secondary technical schools, consultation of entering a school of a higher grade, and application and academic research of curriculum planning.
\end{abstract}

Keywords: criteria, hospitality and catering, Modified Delphi Method, Analytic Hierarchy Process (AHP)

\section{INTRODUCTION}

The atmosphere of entering a school of a higher grade leads the policy implementation as well as curriculum design and planning of education-related units and affects social value and the status quo of the hospitality and catering industry. The Taiwanese government implemented one day off and two-day off per week by turns in 1998 and implemented two-day off per week in 2001. Taiwanese become more concerned about the quality of leisure life than ever before. The hospitality and catering industry is a part of leisure service industry. The policy of two-day off per week drives its vigorous development and raises the demands for talents in this aspect and the importance attached to education of hospitality and catering (Ko, 2002). In view of this, in order to adapt to the growth trend of hospitality and catering industry and the increasing demands for professional talents, the education authorities promote vocational colleges, higher colleges of technology, and universities of science and technology to set up majors related to hospitality and catering so as to actively cultivate practiceoriented talents and enhance the service quality of the hospitality and catering industry.

To students, the good skills and career preparation obtained from these colleges and universities facilitate their life-long career development. However, recently, due to different systems for entering a school of a higher grade, increasing problems of students, lack of teachers, and changes in family structure, it becomes a topic worth of exploration if schools can provide appropriate and suitable career guidance to help and guide students make appropriate career choices. Therefore, based on the key influence of education on the country, especially enhancing the quality of technical personnel, combining with industrial development needs, this study employed "Modified Delphi Method" and "AHP" to conduct questionnaire to identify the factors influencing students' selection of the majors related to hospitality and catering and hoped that the education authorities would plan more reasonable allocation of educational resources in the future.

\section{LITERATURE REVIEW}

\subsection{The Status Quo of the Majors Related to Hospitality and Catering}

Rapid economic growth drives the vigorous development of tourism and hospitality business. In line with this trend, vocational education offered the education of hospitality and catering to cultivate 


\section{Yi-Hsueh Shen}

talents to meet market demands. The government attached great importance to the development of education of hospitality and catering and the public actively got involved in it (Yang, 1999). The dramatic increase of departments of hospitality and catering over the past five years resulted in the increase of hospitality and catering management departments, indicating the significant status of hospitality and catering management departments at the primary stage of education of hospitality and catering.

Though hospitality and catering management departments had been set up for a short period of time, no matter the number of classes or students enrolled rose year by year with strong development potential. Plus, the demands for talents in this aspect, especially basic service staff, education of hospitality and catering has a huge development space (Hao, 1998). The hospitality and catering management majors at this stage are often set up according to the current social demands, which not only offer talents required by the hospitality and catering industry, but also enhance the quality of the hospitality and catering industry. Most teachers, students, and practitioners in the industry assume it necessary to increase the majors of hospitality and catering. Recent years witnessed the prosperity of sightseeing and hospitality \& catering industry in Taiwan. Vocational education of hospitality and catering responds to this trend to actively cultivate talents to meet market demands. Though hospitality and catering management departments had been set up for a short period of time, no matter the number of classes or students enrolled rose year by year with strong development potential. The hospitality and catering management majors at this stage are often set up according to the current social demands, which not only offer talents required by the hospitality and catering industry, but also enhance the quality of the hospitality and catering industry. Most teachers, students, and practitioners in the industry assumed it necessary to increase the majors of hospitality and catering (Lin, 1991).

\subsection{Factors Affecting Graduates' Selection of Majors of Hospitality and Catering}

Through the literature review, many scholars had substantial achievement in terms of the factors affecting students' selectin of majors of hospitality and catering. The results of many studies in the past implied that the selection of entering a school of a higher grade was affected by many factors. To make appropriate career selection, one needs to understand his/her own aptitude, interest, ambition, and restriction. During the process, the interaction among the four aspects of individual, family, school, and society turn into vital elements influencing career selection and determining unique career direction of an individual.

The four factors influencing graduates' selection of majors of hospitality and catering, namely, personal factors, family, school, and society, are described as follows:

\section{(1) Personal Factors}

In addition to the influence of external environment, adolescents must take into account many personal factors. The factors influencing students' selection of majors of hospitality and catering included "interest", "aptitude", and "understanding of the work of hospitality and catering" (Chiang, 2002).

\section{(2) Family Factors}

"Family" is the basic unit of a society. Since his/her birth, an individual is affected by his/her family all the time. Family environment is likely to influence the results of education. The family factors influencing students' selection of majors of hospitality and catering included "parents' occupations", "parental education attitude", and "parents' expectations" (Hung, 2001), which are described as follows:

1. Parents' Occupations: During childhood, one is influenced by what he/she constantly sees and hears about the works of his/her parents. The works and occupations of their parents are the earliest recognition of them, which turn into an intangible influence affecting some of their value.

2. Parental Education Attitude: Parental education attitude often affects their children's learning motivation, methods, and content. Positive attitude facilitates children to build up their academic performance and confidence and indirectly affects their education outcomes. Hsien-chin Hung found that the proportion of the influence of parental encouragement on the willingness of entering a school of a higher grade of children accounted for $92 \%$ (Hung, 2001).

3. Parents' Expectations: Parents and adolescents need to understand each other's expectations so as to discuss career development planning of the latter. Hung-wen Li pointed out that in the 
selection of entering a school of a higher grade by children, the influence of relative expectations of parents was significant (Li, 2002).

\section{(3) School Factors}

In recent years, students spend longer time in school. Schools play a critical role in terms of the willingness and attitude of entering a school of a higher grade of students. The school factors influencing students' selection of majors of hospitality and catering included "peer influence", "consulting measures on entering a school of a higher grade of students", "teaching materials of vocational schools", and "equipment and environment of vocational schools" (Wu, 2001), which are described as follows:

1. Peer Influence: Peer is a group with the most important and powerful influence on an individual during socialization besides parents and teachers.

Peer is also one of the factors affecting one's willingness and decision of entering a school of a higher grade.

2. Consulting Measures on Entering a School of a Higher Grade of Students: The setup of "Executive Committee of Education Tasks for Career Development" and the compilation of "Handbook on Student Career Consultation" have obvious influences on students.

3. Type of Vocational Schools: The types of vocational schools in Taiwan include public and private vocational schools with the length of schooling of five and two years, which affecting the career decision of students.

4. Teaching Materials of Vocational Schools: The courses and teaching content of vocational schools are closely linked to the academic outcomes of students. They have become one of the key factors considered by more and more students when they select school recently.

5. Equipment and Environment of Vocational Schools: In line with the trends of the era, students pay more attention to the quality of school environment. Hence, the equipment and environment of vocational schools have become one of the factors influencing students' career.

\section{(4) Social Factors}

Social factors are extensive, but those touched by students are limited. The social factors influencing students' selection of majors of hospitality and catering included "social value", "celebrity effect", "economic condition", and "future employment opportunities" which are described as follows:

1. Social Value: The value stressed by the society included reputation, status, remuneration, educational background, contribution to the society, and nature of work, which seemed to be the indicators affecting one's career development (Tsai, 2003).

The general ideas on "hospitality and catering" have an intangible influence on the inner world of students.

2. Celebrity Effect: Affected by the mass media, sports stars, singers, actors, and celebrities are praised by the public.

And their occupations are longed for by many. "Fame" becomes a standard to assess one's value. The popular chiefs like Cheng Yen-chi and Wu Pao-chun deeply influence students.

3. Economic Condition: Studies showed that many countries were affected financial crisis. Taiwan also suffered from economic downturn. Unemployment rate is on the rise. Thus, graduates of vocational schools continued to study so as to shun away from the economic downtown ( $\mathrm{Li}, 2001)$.

4. Future Employment Opportunities: Economic conditions lead to many or few employment opportunities. The ideas of selection of continuous study to avoid the economic downturn and seeking opportunities of direct employment both make sense and affect the selection of students.

\subsection{Delphi Method and AHP}

Delphi Method was first proposed by Helmer and Gordon in the 1940s. It is a method in which a group participates anonymously. Experts receiving the interviews form consensus through several rounds of questionnaire via specific procedures and repeated discussion based on their past relevant 


\section{Yi-Hsueh Shen}

knowledge, experience, and opinions. The method of implementation of Modified Delphi Method (Linstone, 1978) is almost the same as that of Delphi Method. Only the first round of open-ended questionnaire is changed to literature review and interview of experts so as to save much time. And the experts can focus on the research topic without the need to fill in the open-ended questionnaire. The recovery rate of the questionnaire is also raised. Also, consensus among the experts can also be achieved.

AHP is a set of decision-making methods put forward by Professor Thomas L. Saaty of University of Pittsburgh in the 1970s, mainly applied to the decision-making problems with multiple evaluation criteria. The connotations of AHP proposed by Saaty included: Through systematic breakdown and stratification of problems, relative importance of elements was concluded by pairwise comparison. The order to solutions was listed to serve as the basis of selection of the best solution (Saaty, 1990).

\section{RESEARCh Method}

This study collected relevant literature, adopted Modified Delphi Method to summarize the opinions of experts, analyzed the primary and secondary influencing criteria, employed Analytic Hierarchy Process (AHP) to analyze samples to determine the relative weight of each criterion, and concluded the weight relationship of the factors influencing graduates of senior middle schools majoring in hospitality and catering. The research steps are described as follows:

\subsection{Analysis of Relevant Literature}

This study collected and summarized the literatures related to factors influencing career selection and intention of entering a school of a higher grade of several scholars and primarily proposed four aspects and 22 evaluation criteria influencing the selection of majors of hospitality and catering, as shown in Table 1.

Table1. Primarily proposed aspects and evaluation criteria influencing the selection of majors of hospitality and catering by students

\begin{tabular}{|c|c|c|}
\hline Tier 1 & Tier 2 & Tier 3 \\
\hline Objective & Primary criteria & Secondary criteria (evaluation criteria) \\
\hline \multirow{22}{*}{$\begin{array}{l}\text { Factors affecting } \\
\text { students' selection of } \\
\text { majors of hospitality } \\
\text { and catering }\end{array}$} & \multirow{6}{*}{ Personal factors } & Gender \\
\hline & & Interest \\
\hline & & Aptitude \\
\hline & & Academic achievement \\
\hline & & Work experience \\
\hline & & Understanding of the work of hospitality and catering \\
\hline & \multirow{6}{*}{ Family factors } & Parents' occupations \\
\hline & & Parents' education backgrounds \\
\hline & & Parental education attitude \\
\hline & & Parents' expectations \\
\hline & & Family income \\
\hline & & Family social and economic statuses \\
\hline & \multirow{6}{*}{ School factors } & Teachers' expectations \\
\hline & & Peer influence \\
\hline & & $\begin{array}{l}\text { Consulting measures on entering a school of a higher grade of } \\
\text { students }\end{array}$ \\
\hline & & Types of vocational schools \\
\hline & & Teaching materials of vocational schools \\
\hline & & Equipment and environment of vocational schools \\
\hline & \multirow{4}{*}{ Social factors } & Social value \\
\hline & & Celebrity effect \\
\hline & & Economic condition \\
\hline & & Future employment opportunities \\
\hline
\end{tabular}

\subsection{Summary of the Opinions of Experts through Interview and Modified Delphi Method and the Establishment of the Evaluation Criteria}

In the first round of Modified Delphi Method questionnaire, semi-open 5-point Likert Scale was used. The copies of questionnaire were distributed to relevant scholars. After they were collected, the scores, opinions, and comments of the experts were analyzed and summarized. The recovery rate of the first round of questionnaire was $100 \%$. The results show that the average of "gender" was less than 3.5 with the proportion smaller than $70 \%$. The proportion of "teachers" expectations" was smaller 
than $70 \%$. According to the evaluation criteria of the first round, the two factors "were not important". And the experts "did not have consensus on them". Thus, they were deleted and would not appear in the second round. The averages and standard deviations of all the other 20 factors were in line with the evaluation criteria and the standards proposed by Wen-liang Chen and Tzu-hua Chen (Chen, 2011). The recovery rate of the second round of questionnaire was $100 \%$. The results show that the averages of "academic achievement", "work experience", "parents' education backgrounds", "family income", and "family social and economic statuses" were less than 3.8 with the proportion smaller than $75 \%$. According to the evaluation criteria of the second round, the five factors "were not important". And the experts "did not have consensus on them". Thus, they were deleted.

\subsection{Establishment of a Hierarchical Research Framework}

Based on the two rounds of Delphi Method questionnaire, Tier 2 of this study covered four aspects and tier 3 contained 15 evaluation factors, which are in line with the principle of having less than 7 factors in each tier suggested by Saaty (Saaty, 1990). The meanings of the 15 evaluation criteria in the research framework are described in Table 4.

Table2. Explanation of the meanings of the evaluation criteria influencing the selection of majors of hospitality and catering by students

\begin{tabular}{|c|c|c|}
\hline \multirow[t]{3}{*}{$\begin{array}{l}\text { Personal } \\
\text { factors }\end{array}$} & Interest & $\begin{array}{l}\text { Motivation leads to behaviors and concentration on a subject. } \\
\text { The outcome can produce the sense of satisfaction for several } \\
\text { times. The inclination to repeat such behavior is interest. }\end{array}$ \\
\hline & Aptitude & It refers to the potential ability of one thing before learning. \\
\hline & $\begin{array}{l}\text { Understanding of the } \\
\text { work of hospitality and } \\
\text { catering }\end{array}$ & $\begin{array}{l}\text { It refers to the opinions, ideas, and judging standards of an } \\
\text { individual on the work of hospitality and catering. }\end{array}$ \\
\hline \multirow{3}{*}{$\begin{array}{l}\text { Family } \\
\text { factors }\end{array}$} & Parents' occupations & It refers to nature and content of the works of parents. \\
\hline & Parental education attitude & $\begin{array}{l}\text { It refers to the unconscious influence of the cultivation, } \\
\text { education, personal example, verbal instruction, belief, emotion, } \\
\text { and attitude of parents on the all-round development of children. }\end{array}$ \\
\hline & Parents' expectations & Parents hope or require their children to have certain behaviors. \\
\hline \multirow[t]{5}{*}{$\begin{array}{l}\text { School } \\
\text { factors }\end{array}$} & Peer influence & $\begin{array}{l}\text { It refers to the relationship and interaction among classmates } \\
\text { which have a direct or indirect influence on individual. }\end{array}$ \\
\hline & $\begin{array}{l}\text { Consulting measures on } \\
\text { entering a school of a } \\
\text { higher grade of students }\end{array}$ & $\begin{array}{l}\text { All kinds of measures are adopted to provide consultation to } \\
\text { students in terms of entering a school of a higher grade. }\end{array}$ \\
\hline & $\begin{array}{l}\text { Types of vocational } \\
\text { schools }\end{array}$ & The types of vocational schools in Taiwan. \\
\hline & $\begin{array}{l}\text { Teaching materials of } \\
\text { vocational schools }\end{array}$ & $\begin{array}{l}\text { Learning activities and other contents of vocational schools in } \\
\text { Taiwan. }\end{array}$ \\
\hline & $\begin{array}{c}\text { Equipment and } \\
\text { environment of vocational } \\
\text { schools } \\
\end{array}$ & Equipment and environment of vocational schools in Taiwan. \\
\hline \multirow[t]{4}{*}{$\begin{array}{l}\text { Social } \\
\text { factors }\end{array}$} & Social value & $\begin{array}{l}\text { The value and opinions on "hospitality and catering" of the } \\
\text { whole society. }\end{array}$ \\
\hline & Celebrity effect & $\begin{array}{l}\text { Affected by mass media, celebrities known to the public often } \\
\text { are praised by the public. }\end{array}$ \\
\hline & Economic condition & The economic condition of the whole society. \\
\hline & $\begin{array}{c}\text { Future employment } \\
\text { opportunities }\end{array}$ & The job opportunities obtained after study. \\
\hline
\end{tabular}

\subsection{AHP Questionnaire}

First, the questionnaire was conducted. Second, the invalid copies were excluded. Finally, the valid copies were analyzed and explained via computer software. And suggestions were proposed based on the results.

\subsection{Data Analysis}

Quantitative analysis had been conducted for the valid copies of questionnaire collected to learn the evaluation criteria influencing the selection of majors of hospitality and catering by students and their weights in decision-making. 


\subsection{Conclusions and Suggestions}

Based on the research results, relevant suggestions were proposed to serve as reference for educational and administrative organs, educational decision makers, policy promotion of vocational schools, consultation of entering a school of a higher grade, and application and academic research of curriculum planning.

\section{RESEARCH RESULTS}

After the AHP questionnaire was collected, AHP had been conducted in three parts: Part 1 was the objective level, that is, the expected objective to be completed by this study - "understanding the factors influencing students' selection of majors of hospitality and catering". Part 2 was about primary evaluation criteria. Part 3 was about secondary evaluation criteria, including the 15 items covered in personal factors, family factors, school factors, and social factors. Expert Choice was employed to analyze the data. The averages and weights were obtained through pairwise comparison. Then comparison matrix was formed to obtain advantage vector and characteristic value and see if the consistency verification was acceptable.

\subsection{Importance Analysis of the Primary Criteria Influencing the Selection of Majors of Hospitality and Catering by Students}

First, the questionnaire results on the primary criteria were analyzed. Four primary criteria were compared pairwise for a total of $4 *(4-1) / 2=6$ times. "Personal factors" were set as $w_{1}$, "family factors" as $w_{2}$,"school factors" as $w_{3}$, and "social factors" as $w_{4}$. Through Eq. (1), the weights of primary criteria were calculated as follows:

$$
w_{1}=\frac{1}{n} \sum_{j}^{n} \frac{a_{i j}}{\sum_{i=1}^{n} a_{i j}}=\frac{1}{4}\left(\frac{1}{1.8694}+\frac{2.1313}{3.9447}+\frac{3.8045}{9.0247}+\frac{2.6665}{7.7576}\right)=0.4601
$$

Through Eq. (2), the consistency of primary criteria was calculated. wi was calculated by Eq.2-2. Then, consistency vector was calculated:

Consistency vector

$$
\begin{aligned}
& v_{i}=\sum_{j=1}^{n} w_{j} a_{i j} / w_{i} \\
= & (0.4601 * 1+0.2577 * 2.1313+0.1528 * 3.8045+0.1294 * 2.6665) / 0.4601 \\
= & 4.2066
\end{aligned}
$$

The consistency vectors of the four primary criteria were calculated in order. Their average was $\lambda$ max value.

$\lambda \max =(4.2066+4.5677+4.1602+3.9477) / 4=4.2055$

C.I. and C.R. values were calculated according to the formula.

$$
\begin{gathered}
\begin{aligned}
C I= & \left(\lambda_{\max }-n\right) /(n-1) \\
= & (4.2055-4) /(4-1) \\
& =0.0735 \\
\text { C.R. } & =\text { C.I. } / \text { R.I. } \\
= & 0.0735 / 0.90 \\
= & 0.0817
\end{aligned}
\end{gathered}
$$

The weights of the four primary criteria were calculated based on the formula. The pairwise matrix of the primary criteria was described in Table 3: 
Study on the Factors Affecting Senior Middle School Students' Selection of Majors of Hospitality and Catering

Table3. Importance analysis of the primary criteria influencing the selection of majors of hospitality and catering by students

\begin{tabular}{|c|c|c|c|c|c|c|}
\hline Primary criteria & Personal factors & Family factors & School factors & Social factors & Weights & Ranking \\
\hline Personal factors & 1 & 4.040 & 4.381 & 2.830 & 0.523 & 1 \\
\hline Family factors & 0.248 & 1 & 3.269 & 2.157 & 0.237 & 2 \\
\hline School factors & 0.228 & 0.306 & 1 & 1.432 & 0.119 & 4 \\
\hline Social factors & 0.353 & 0.464 & 0.698 & 1 & 0.121 & 3 \\
\hline Column total & 1.829 & 5.809 & 9.349 & 7.419 & 1 & \\
\hline
\end{tabular}

$\lambda \max =4.207$, C.I. $=0.074$, C.R. $=0.082$ in line with the requirements of consistency

\subsection{Importance Analysis of the Secondary Criteria Influencing the Selection of Majors of Hospitality and Catering by Students}

The importance of the secondary criteria was analyzed by the four main factors. The results are shown as follows. The secondary criteria of personal factors included "interest", "aptitude", and "understanding of the work of hospitality and catering". Through the pairwise comparison of the influencing factors, the comparison matrix was described in Table 4.

Table4. Importance analysis of the secondary criteria of personal factors

\begin{tabular}{|c|c|c|c|c|c|}
\hline Personal factors & Interest & Aptitude & $\begin{array}{c}\text { Understanding of the work of } \\
\text { hospitality and catering }\end{array}$ & $\begin{array}{c}\text { Weig } \\
\text { hts }\end{array}$ & $\begin{array}{c}\text { Ranki } \\
\text { ng }\end{array}$ \\
\hline Interest & 1 & 4.382 & 3.425 & 0.648 & 1 \\
\hline Aptitude & 0.228 & 1 & 1.841 & 0.204 & 2 \\
\hline $\begin{array}{c}\text { Understanding of the work of } \\
\text { hospitality and catering }\end{array}$ & 0.292 & 0.543 & 1 & 0.148 & 3 \\
\hline Column total & 1.520 & 5.925 & 6.265 & 1 & \\
\hline
\end{tabular}

$\lambda \max =3.083$ C.I. $=0.042$ C.R. $=0.072$ in line with the requirements of consistency.

The secondary criteria of family factors included "parents' occupations", "parental education attitude", and "parents' expectations". Through the pairwise comparison of the influencing factors, the comparison matrix was described in Table 5.

Table5. Importance analysis of the secondary criteria of family factors

\begin{tabular}{|c|c|c|c|c|c|}
\hline Family factors & $\begin{array}{c}\text { Parents' } \\
\text { occupations }\end{array}$ & $\begin{array}{c}\text { Parental education } \\
\text { attitude }\end{array}$ & $\begin{array}{c}\text { Parents' } \\
\text { expectations }\end{array}$ & Weights & Ranking \\
\hline Parents' occupations & 1 & 1.264 & 0.707 & 0.321 & 3 \\
\hline $\begin{array}{c}\text { Parental education } \\
\text { attitude }\end{array}$ & 0.791 & 1 & 1.375 & 0.342 & 1 \\
\hline Parents' expectations & 1.415 & 0.727 & 1 & 0.336 & 2 \\
\hline Column total & 3.206 & 2.991 & 3.082 & 1 & \\
\hline
\end{tabular}

$\lambda \max =3.091$ C.I. $=0.045$ C.R. $=0.078$ in line with the requirements of consistency

The secondary criteria of school factors included "peer influence", "consulting measures on entering a school of a higher grade of students", "types of vocational schools", "teaching materials of vocational schools", and "equipment and environment of vocational schools". Through the pairwise comparison of the influencing factors, the comparison matrix was described in Table 6.

Table6. Importance analysis of the secondary criteria of school factors

\begin{tabular}{|c|c|c|c|c|c|c|c|}
\hline School factors & $\begin{array}{c}\text { Peer } \\
\text { influence }\end{array}$ & $\begin{array}{c}\text { Consulting } \\
\text { measures on } \\
\text { entering a } \\
\text { school of a } \\
\text { higher grade } \\
\text { of students }\end{array}$ & $\begin{array}{c}\text { Types } \\
\text { of } \\
\text { vocatio } \\
\text { nal } \\
\text { schools }\end{array}$ & $\begin{array}{c}\text { Teaching } \\
\text { materials } \\
\text { of } \\
\text { vocational } \\
\text { schools }\end{array}$ & $\begin{array}{c}\text { Equipment } \\
\text { and } \\
\text { environment } \\
\text { of } \\
\text { vocational } \\
\text { schools }\end{array}$ & Weights & Ranking \\
\hline Peer influence & 1 & 2.450 & 1.572 & 1.678 & 1.231 & 0.287 & 1 \\
\hline $\begin{array}{c}\text { Consulting } \\
\text { measures on } \\
\text { entering a } \\
\text { school of a }\end{array}$ & 0.408 & 1 & 1.308 & 1.100 & 1.339 & 0.181 & 3 \\
\hline
\end{tabular}




\begin{tabular}{|c|c|c|c|c|c|c|c|}
\hline \hline $\begin{array}{c}\text { higher grade of } \\
\text { students }\end{array}$ & 0.636 & 0.764 & 1 & 2.038 & 1.618 & 0.210 & 2 \\
\hline $\begin{array}{c}\text { Types of } \\
\text { vocational } \\
\text { schools }\end{array}$ & 0.596 & 0.909 & 0.491 & 1 & 1.561 & 0.159 & 5 \\
\hline $\begin{array}{c}\text { Teaching } \\
\text { materials of } \\
\text { vocational } \\
\text { schools }\end{array}$ & 1.231 & 0.747 & 0.618 & 0.640 & 1 & 0.163 & 4 \\
\hline $\begin{array}{c}\text { Equipment and } \\
\text { environment of } \\
\text { vocational } \\
\text { schools }\end{array}$ & & & & & & & \\
\hline Column total & 3.871 & 5.870 & 4.990 & 6.457 & 6.748 & 1 & \\
\hline
\end{tabular}

$\lambda \max =5.353$ C.I. $=0.088$ C.R. $=0.079$ in line with the requirements of consistency

The secondary criteria of social factors included "social value", "celebrity effect", "economic condition", and "future employment opportunities". Through the pairwise comparison of the influencing factors, the comparison matrix was described in Table 7.

Table7. Importance analysis of the secondary criteria of social factors

\begin{tabular}{|c|c|c|c|c|c|c|}
\hline Social factors & $\begin{array}{c}\text { Social } \\
\text { value }\end{array}$ & $\begin{array}{c}\text { Celebrity } \\
\text { effect }\end{array}$ & $\begin{array}{c}\text { Economic } \\
\text { condition }\end{array}$ & $\begin{array}{c}\text { Future employment } \\
\text { opportunities }\end{array}$ & Weights & Ranking \\
\hline Social value & 1 & 3.391 & 1.270 & 1.216 & 0.358 & 1 \\
\hline Celebrity effect & 0.295 & 1 & 0.999 & 0.613 & 0.160 & 4 \\
\hline Economic condition & 0.787 & 1.001 & 1 & 1.392 & 0.249 & 2 \\
\hline $\begin{array}{c}\text { Future employment } \\
\text { opportunities }\end{array}$ & 0.822 & 1.632 & 0.718 & 1 & 0.233 & 3 \\
\hline Column total & 2.905 & 7.025 & 3.987 & 4.221 & 1 & \\
\hline
\end{tabular}

$\lambda \max =4.132$ C.I. $=0.022$ C.R. $=0.049$ in line with the requirements of consistency.

\subsection{Comprehensive Analysis of the Factors Influencing the Selection of Majors of Hospitality and Catering by Students}

Through the comprehensive analysis, the rankings of weights are listed in Table 8 through which we can learn the relative importance among the factors.

Table8. Comprehensive importance analysis of the factors

\begin{tabular}{|c|c|c|c|c|c|}
\hline $\begin{array}{l}\text { Primary } \\
\text { Criteria }\end{array}$ & Weight & Secondary Criteria & Weight & $\begin{array}{l}\text { Comprehensive } \\
\text { Weight }\end{array}$ & Ranking \\
\hline \multirow{3}{*}{$\begin{array}{l}\text { Personal } \\
\text { factors }\end{array}$} & \multirow[t]{3}{*}{0.523} & Interest & 0.648 & 0.339 & 1 \\
\hline & & Aptitude & 0.204 & 0.107 & 2 \\
\hline & & $\begin{array}{c}\text { Understanding of the work of hospitality } \\
\text { and catering }\end{array}$ & 0.148 & 0.077 & 5 \\
\hline \multirow{3}{*}{$\begin{array}{l}\text { Family } \\
\text { factors }\end{array}$} & \multirow[t]{3}{*}{0.237} & Parents' occupations & 0.321 & 0.076 & 6 \\
\hline & & Parental education attitude & 0.342 & 0.081 & 3 \\
\hline & & Parents' expectations & 0.336 & 0.080 & 4 \\
\hline \multirow{5}{*}{$\begin{array}{l}\text { School } \\
\text { factors }\end{array}$} & \multirow[t]{5}{*}{0.119} & Peer influence & 0.287 & 0.034 & 8 \\
\hline & & $\begin{array}{l}\text { Consulting measures on entering a } \\
\text { school of a higher grade of students }\end{array}$ & 0.181 & 0.022 & 12 \\
\hline & & Types of vocational schools & 0.210 & 0.025 & 11 \\
\hline & & Teaching materials of vocational schools & 0.159 & 0.019 & 15 \\
\hline & & $\begin{array}{l}\text { Equipment and environment of } \\
\text { vocational schools }\end{array}$ & 0.163 & 0.019 & 13 \\
\hline \multirow{4}{*}{$\begin{array}{l}\text { Social } \\
\text { factors }\end{array}$} & \multirow[t]{4}{*}{0.121} & Social value & 0.358 & 0.043 & 7 \\
\hline & & Celebrity effect & 0.160 & 0.019 & 14 \\
\hline & & Economic condition & 0.249 & 0.030 & 9 \\
\hline & & Future employment opportunities & 0.233 & 0.028 & 10 \\
\hline
\end{tabular}

Based on the above comprehensive calculation results, we can see that while considering the selection of majors of hospitality and catering, students attach the greatest importance to personal factors with the highest weight of 0.5223. In the analysis of a single factor, most attention has been attached to "interest" in personal factors, "parental education attitude" in family factors, "peer influence" in school factors, and "social value" in social factors. 
Generally speaking, the analysis of the four primary criteria and 15 secondary criteria indicate that, the Top 5 weights in order are interest (0.339), aptitude (0.107), parental education attitude $(0.081)$, parents' expectations (0.080), and understanding of the work of hospitality and catering (0.077). The total weights of the five criteria accounts for $68.4 \%$. This study classifies the five criteria as the influencing factors "with high attention" of students. The Top 6-10 weights in order are parents' occupations (0.076), social value (0.043), peer influence (0.034), economic condition (0.030), and future employment opportunities (0.028). The total weights of the five criteria accounts for $21.1 \%$. This study classifies the five criteria as the influencing factors "with moderate attention" of students, while the rest as the influencing factors "with low attention" of students. See Table 9.

Table9. Importance attached to the evaluation criteria of graduates of middle schools

\begin{tabular}{|c|c|c|c|c|}
\hline $\begin{array}{l}\text { Weights } \\
\text { Ranking }\end{array}$ & $\begin{array}{l}\text { Degree of Attention } \\
\text { (Proportion) }\end{array}$ & Evaluation Criteria & $\begin{array}{l}\text { Comprehensive } \\
\text { Weight } \\
\text { Distribution }\end{array}$ & Aspect \\
\hline 1 & \multirow{5}{*}{$\begin{array}{l}\text { High attention } \\
68.4 \%\end{array}$} & Interest & 0.339 & Personal factors \\
\hline 2 & & Aptitude & 0.107 & Personal factors \\
\hline 3 & & Parental education attitude & 0.081 & Family factors \\
\hline 4 & & Parents' expectations & 0.080 & Family factors \\
\hline 5 & & $\begin{array}{l}\text { Understanding of the work } \\
\text { of hospitality and catering }\end{array}$ & 0.077 & Personal factors \\
\hline 6 & \multirow{5}{*}{$\begin{array}{l}\text { Moderate attention } \\
21.1 \%\end{array}$} & Parents' occupations & 0.076 & Family factors \\
\hline 7 & & Social value & 0.043 & Social factors \\
\hline 8 & & Peer influence & 0.034 & School factors \\
\hline 9 & & Economic condition & 0.030 & Social factors \\
\hline 10 & & $\begin{array}{l}\text { Future employment } \\
\text { opportunities }\end{array}$ & 0.028 & Social factors \\
\hline 11 & \multirow[t]{5}{*}{$\begin{array}{l}\text { Low attention } \\
10.5 \%\end{array}$} & $\begin{array}{l}\text { Types of vocational } \\
\text { schools }\end{array}$ & 0.025 & School factors \\
\hline 12 & & $\begin{array}{l}\text { Consulting measures on } \\
\text { entering a school of a } \\
\text { higher grade of students }\end{array}$ & 0.022 & School factors \\
\hline 13 & & $\begin{array}{l}\text { Equipment and } \\
\text { environment of vocational } \\
\text { schools }\end{array}$ & 0.019 & School factors \\
\hline 14 & & Celebrity effect & 0.019 & Social factors \\
\hline 15 & & $\begin{array}{l}\text { Teaching materials of } \\
\text { vocational schools }\end{array}$ & 0.019 & School factors \\
\hline
\end{tabular}

The overall research results show that "personal factors" have important influences. Among the Top 5 criteria, there are three from personal factors, indicating that interest, aptitude, and understanding of the work of hospitality and catering have major influences on the selection of majors in hospitality and catering. They also have influences, predicative power, consistency, and continuity, directly influence individual decision-making model, and become the most significant factors influencing the selection of majors in hospitality and catering by students.

\section{Conclusion}

In terms of the primary criteria, this study adopted two rounds of Modified Delphi Method questionnaire to confirm four primary criteria, namely, personal factors, family factors, school factors, and social factors. Through AHP, the most important criterion is personal factors, followed by family factors, social factors, and school factors in order. Based on the results, further study and analysis had been carried out. Personal factors have the highest overall weight, accounting for 52.3\%, indicating that personal factors are key to students when they select to major in hospitality and catering. The results can service as reference for relevant education units.

With respect to the secondary criteria, this study adopted two rounds of Modified Delphi Method questionnaire to confirm 15 secondary criteria. Through AHP, the importance of the secondary criteria in order are: 1. Interest, 2. aptitude, 3. parental education attitude, 4. parents' expectations, 5. understanding of the work of hospitality and catering, 6. parents' occupations, 7. social value, 8. peer influence, 9. economic condition, 10. future employment opportunities, 11. types of vocational schools, 12. consulting measures on entering a school of a higher grade of students, 13. equipment 
and environment of vocational schools, 14. celebrity effect, and 15 teaching materials of vocational schools.

On the basis of the above research conclusions, in respect to the future entering a school of a higher grade, students first consider their own interest and aptitude, and then the education attitude and expectations of their parents. Thus, it is suggested that educational and administrative organs and schools shall actively help students explore their interest and aptitude so as to help them identity suitable goals. Meanwhile, it is suggested that parents shall discuss with their children about the future development of the latter.

\begin{tabular}{|l|l|l|l|}
\hline \multirow{3}{*}{ Price } & 3 & Capacity to respond to emergency \\
\cline { 2 - 4 } & & 1 & Reasonable prices \\
\cline { 2 - 3 } & 2 & Discount of service \\
\cline { 2 - 3 } & 3 & Reasonable price composition \\
\hline
\end{tabular}

\section{REFERENCES}

[1] Chen, W.L., Chen, T.H. (2011). Study on the Establishment of Ready-made Clothes Design Indicators with Modified Delphi Method and AHP, Journal of Humanities and Social Sciences, 7: 1, 49-59.

[2] Chiang, C.C. (2002). Restaurant Management Program's Senior Students' Education and Career Perspectives. Master's Thesis, Master's Program of Housekeeping Education Department, National Taiwan Normal University, Taipei City.

[3] Hao, C.W. (1998). The investigation of the present circumstance of the food and beverage department at senior high school level in northern Taiwan. Unpublished, Master's Thesis, Housekeeping Education Department, National Taiwan Normal University, Taipei City.

[4] Hung, H.C. (2001). A Study of the Intention for and Attitude to Further Education of Students in Tourism Program in Vocational High Schools in the Republic of China. Master's Thesis, Department of Leisure Services Management, Chaoyang University of Technology, Taichung.

[5] Ko, S.P. (2002). The Study of Student's Learning Satisfaction of Vocational High School in the Food and Beverage Management Department--Example in the Taoyuan Area, Master's Thesis, Department of Tourism, Shih Hsin University, Taipei.

[6] Length of Schooling of De Lin Institute of Technology. National Education Research Institute, Taipei Municipal University of Education, Taipei.

[7] Li, C.C. (2001). Investigation on the Willingness of Entering a School of a Higher Grade and Employment of Two-year Vocational School Students A Cast Study of the Students of TwoYear

[8] Li, W.H. (2002). Study on the Factors Influencing the Willingness of Entering a School of a Higher Grade of Graduates of Senior Middle Schools and the Corresponding Schools-A Case Study of Changhua County/City. Master's Thesis, Department of Industrial Education and Technology, National Changhua University of Education, Changhua.

[9] Lin, H.H. (1991). Investigation of the Status Quo of the Education Related to Catering Management of Senior Middle Schools and Vocational Schools. Unpublished, Master's Thesis, Housekeeping Research Institute, Private Chinese Culture University, Taipei.

[10] Linstone, H.A. (1978) .The Delphi Method. In J. Fowless (ED.) Hand-book of Futures Research . Londen: Greenwood Press, PP.273-300.

[11] Saaty, T. L. (1990). The Analytic Hierarchy Process, RWS Publications, Pittsburgh, PA.

[12] Tsai, L.H. (2003). A Study of the Factors Influencing Senior Vocational School Students of Cosmetology Aspiration for Higher Education. Master's Thesis, Graduate Institute of Technological and Vocational Education, National Taipei University of Technology, Taipei.

[13] Wu, W.C. (2001). A Study on the Factors Influencing Aspirations \& Path-Choices of Pursuing a Higher Education for the Daytime Students of Department of Controlling Vocational High School in Taiwan, R.O.C. Master's Thesis, Department of Industrial Education, National Taiwan Normal University, Taipei.

[14] Yang, H.T. (1999). Study on the Satisfaction of the Work of Teachers of Hospitality and Catering Departments of Senior Middle Schools and Vocational Schools. Master's Thesis, Department of Applied Science of Living, Private Chinese Culture University, Taipei City. 